\title{
Industrial Wage Inequality in Latin America in Global Perspective, 1900-2000
}

\author{
Ewout Frankema
}

Published online: 8 October 2011

(C) The Author(s) 2011. This article is published with open access at Springerlink.com

\begin{abstract}
Standard economic theories of wage inequality focus on the factor-biased nature of technological change and globalization. This paper examines the long-run development of industrial wage inequality in Latin America from a global comparative perspective. We find that wage inequality was comparatively modest during the first half of the twentieth century, but rising much faster during the postwar era than in other industrial countries. In-depth analyses of wage inequality trends in Argentina, Brazil, and Chile confirm this pattern, but also reveal notable country peculiarities. In Argentina and Chile, trend breaks coincided with large politicalinstitutional shocks while in Brazil, wage inequality increased unabated under the wage regulation policies of successive post-war administrations. We argue that without taking national policies with respect to education and the labor market into account, economic theory cannot explain "Latin American" patterns of wage inequality.
\end{abstract}

Keywords Latin America · Wage inequality · Factor income distribution ·

Globalization · Skill-biased technological change

\section{Introduction}

Despite its longstanding historical legacy of high income and wealth inequality, the gap between rich and poor has further widened in the majority of Latin American countries (LACs henceforth) during the final quarter of the twentieth century. This development corresponded with a rise in the aggregate poverty head count ratio in the region as a whole (Psacharopoulos et al. 1997; Londoño and Székely 2000; Morley 2001; Székely and Montes 2006). Some scholars argue that the roots of current Latin American inequality can be traced far back into the colonial era, and

E. Frankema $(\bowtie)$

Faculty of Humanities, Utrecht University, Utrecht, Netherlands

e-mail: e.frankema@uu.nl 
persisted until today through institutions protecting political and economic privileges and suppressing processes of democratization and civil emancipation.

This idea is corroborated by comparative empirical research showing that the development of public education and participatory political systems was notably slower than in North America (Engerman and Sokoloff 1997; 2005; Mariscal and Sokoloff 2000). Factor market imperfections constrained the accumulation of physical and human capital, reducing long-term economic growth and intergenerational social mobility (Galor and Zeira 1993; De Soto 2000; Mookerjee and Ray 2000; Kay 2001). The authoritative World Bank report Inequality in Latin America. Breaking with History? voices the "persistent inequality" view by stating that in its modern form "high inequality is rooted in exclusionary institutions that have been perpetuated ever since colonial times and that have survived different political and economic regimes, from interventionist and import substitution strategies to more market-oriented policies" (De Ferranti et al. 2004: p. 1).

Some economic historians propagate a different perspective, however. Rather than emphasizing the resilient nature of Latin American inequality, they argue that the underlying structure of the income distribution has changed fundamentally in the past two centuries. Stressing the pervasiveness of Latin American inequality neglects the region's distributive dynamics. The literature documenting long-term changes in the structure of the income distribution has been growing rapidly in recent years (Williamson 1999, 2002; Bértola 2005; Prados de la Escosura 2005; Bértola and Williamson 2006; Bértola et al. 2008; Coatsworth 2008; Arroyo Abad and SantosPaulino 2009; Frankema 2009a).

This study aims to contribute to the latter strand of literature by reconstructing long-term series of industrial wage inequality in twentieth century Latin America in a global comparative perspective. The decomposition of income inequality in underlying components offers deeper insight in the secular development of income inequality. Aggregate inequality indicators (such as an income Gini) do not reveal much about the changing determinants of inequality, when the latter affect this indicator in opposite directions. The analysis of partial inequality indicators helps to isolate the effects of changing economic circumstances or political-institutional reforms.

Whereas long-run wage inequality series are extensively documented for many of the highly developed industrialized economies (for a survey, see Helpman 2004: Chapter 6, pp. 94-105), they have not been systematically explored for LACs yet. This has left important questions unanswered. Do we find "general patterns" in Latin American wage inequality? Have wage differentials always been larger in LACs than in other parts of the New World? And to which extent has wage inequality contributed to Latin American "surplus inequality"?

This study addresses these questions by analyzing three types of wage inequality: inter-industry wage inequality, intra-industry wage inequality (i.e., skill premiums), and gender wage gaps. We use a range of inequality measures but rely primarily on the Theil index to investigate changes in the long-run wage inequality trend. The USA, Canada, and Australia are used as New World benchmark countries (NWCs henceforth) to investigate contrasts and similarities. Our results can be summarized in three arguments.

First, wage inequality in the majority of LACs was comparatively modest during the first half of the twentieth century but increased rapidly during the post-war era, 
especially since the mid-1970s. Wage inequality thus appears to be a comparatively novel aspect of Latin American inequality, which has traditionally been dominated by the vast income gaps between minorities of wealthy proprietors and the poverty-stricken masses of mostly unskilled laborers and subsistence farmers (Williamson 1999).

Second, the post-war rise of wage inequality was a shared Latin American phenomenon. It occurred in all 15 LACs for which we were able to construct time series. An in-depth analysis of wage inequality trends in Argentina, Brazil, and Chile reveals notable country peculiarities, however. In Argentina and Chile, wage inequality trend breaks occurred in response to major political-institutional shocks, while in Brazil the post-war rise of wage inequality was gradual and concurred with a strong rise of inter-industry labor productivity differentials. The difference resides in the different nature of labor market policies conducted by successive post-war Brazilian governments.

Third, the explanatory value of standard economic theories of wage inequality, which focus on factor-biased technological change and globalization, has its limitations. While the long-term evolution of wage inequality in LACs may be attributed to the effects of increasing international market integration and skill-biased technological change, economic theory remains silent on the timing and extent of the dramatic breaks in the wage inequality trend observed in Argentina and Chile. We need to look at differences in national labor market policies and educational institutions to understand the impact of global economic developments on national distributional outcomes in Latin America.

The remainder of this study is organized as follows. The "Theories and Hypotheses of Latin American Wage Inequality" section discusses theories of wage inequality. The "Latin American Wage Inequality in Comparative Perspective, 19001950" and "The Post-war Rise of Latin American Wage Inequality, 1950-2000" sections present and discusses the empirical results. "Explaining Long-Term Wage Inequality Trends in Latin America" section offers some tentative explanations for the observed long run patterns by looking in greater detail to the cases of Argentina, Brazil, and Chile. The section on "From Wage Inequality to Income Inequality" discusses the changing relationship between wage and income inequality in these countries. The "Conclusion" section concludes.

\section{Theories and Hypotheses of Latin American Wage Inequality}

In standard economic theory, interpersonal wage gaps are primarily regarded as the result of differentiated market returns to varying physical and mental abilities of employees. Higher levels of human capital are supposed to induce higher levels of labor productivity and these, in turn, are supposed to command a higher market price, all else being equal. In practice, however, interpersonal skill differences tend to coincide with differences in the technological, institutional, and organizational environments in which labor is employed. This makes it notoriously hard to isolate the effect of human capital on productivity and wage differentials. Wage differentials may be taken as a proxy for variation in human capital, but only under the assumption that labor markets adhere to the rules of perfect competition. Few 
scholars would argue that this is an unproblematic assumption. There is always some degree of wage regulation extorted on employers by governments, collective interest groups, and social conventions.

The huge literature on changing wage structures in the industrialized economies center stages two hypotheses that are both embedded in orthodox free market philosophies. The first theory stresses the role of factor-biased technological change (Levy and Murnane 1992; Goldin and Katz 1998; Acemoglu 2002). This theory departs from the assumption that shifts in production technology are usually factorbiased and, during the modern era, more often favor the use of skilled over unskilled labor. Whenever new technologies raise the comparative productivity of skilled labor, the demand for skills will increase. For instance, in recent decades, the computerization of production processes has been associated with a reduced demand for manual and routine cognitive tasks and an increased demand for nonroutine cognitive tasks (Autor et al. 1998, 2003). There is empirical evidence suggesting that these effects have also occurred in middle-income countries, including a number of LACs (Berman and Machin 2000).

A competing theory stresses the role of globalization in explaining changes in wage structures. According to this theory, distributional changes arise from tradeinduced factor price equalization. The increasing integration of international commodity and capital markets during the post-war era has forced economies to specialize according to their comparative advantages. Globalization thus enhanced the employment of low-skilled labor in labor-intensive industries in developing countries competing on the basis of low wage costs. This effect has been associated with the rapid industrialization process in East and South East Asia. In the developed industrial economies, the labor-intensive sectors were driven out of the market, which supported a process of structural change towards technology and skillintensive production activities. This trend however, has put the system of moderate earnings inequality under pressure: intensified schooling and labor training efforts could not prevent that the demand for increasingly specific labor skills rose faster than its supply (Wood 1994; Freeman 1995; Richardson 1995; Feenstra and Hanson 2003).

One of the reasons for the longstanding debate about the primacy of one explanation over the other is that domestic technological change and international market integration tend to reinforce each other, which makes it difficult to isolate their individual effects. Modern technological change and globalization are both favoring skilled labor in the developed industrialized economies (Atkinson and Piketty 2007) and, arguably, both favoring unskilled labor in the newly industrializing countries. Hence, in line with the Stolper-Samuelson theorem of international comparative cost advantages, skill-biased technological change has been part of a broader process of economic specialization in response to global competition.

But there is more. Standard economic theories of wage inequality tend to neglect the role of public policy responses to changing labor market conditions. Governments can directly intervene in wage structures by minimum wage legislation or adjusting public sector wages to private sector developments. Trade unions have a certain degree of bargaining power depending on the legal basis for strikes and other forms of organized collective action. In a more indirect way, governments can diminish wage differentials by removing educational access barriers and allocate 
subsidies training programs in sectors facing skill scarcity. Immigration policies are often factor-biased as well and can work both ways.

While such policy responses may not be of decisive importance in the AngloSaxon economies where wages are primarily set by the market, in the coordinated market economies of Western Europe the impact of government regulation can hardly be neglected. Although skill-biased technological change and globalization have been weakening the position of low-skilled workers in more or less identical ways in both parts of the industrialized world, wage inequality levels in France, the Netherlands, or Sweden have, in contrast to the USA and UK, hardly risen in the past four decades (Atkinson and Piketty 2007).

These theoretical considerations are also relevant for Latin America, as the interaction between changing labor market forces and changing government regulation of the labor market has been intense in many LACs during the twentieth century. We can think of at least three major factors which set LACs apart from the industrialized countries in this respect.

First, during the twentieth century, Latin America transformed from a labor scarce (net receiving) region into a labor-abundant (net sending) region. Extraordinary rates of population growth in the twentieth century deepened the dualistic nature of Latin American labor markets. Dualistic labor markets are characterized by overt differences in human capital, labor rights, capital market access, and social mobility (Perry and Olarreaga 2006; Galiani and Porto 2008). ${ }^{1}$ The limited access of rural migrants to land, education, and investment capital enhanced the supply of lowqualified urban laborers, many of whom ended up in low-productive informal service sector activities with little prospects of social mobility. High access barriers to decent education reproduced socioeconomic inequality (Birdsall et al. 1997; Frankema 2009b; Wegenast 2009; Lindert 2010). A structural oversupply of lowskilled labor occurred in all major Latin American cities, albeit to different degrees (Cardoso and Helwege 1992). ${ }^{2}$

Second, many LACs were deeply engaged in import substitution industrialization (ISI) policies between ca. 1930 and 1980. The political ideologies connected to these ISI programs not only emphasized the need to protect key domestic markets against foreign competition, but also often promoted the emancipation of the urban working class. The absence of international market discipline enabled long-term wage regulation programs that sought to suppress wage gaps across industries and between blue- and white-collar workers. Consequently, the labor market reforms of the 1970s, 1980s, and 1990s unleashed a process of wage adjustments long after demandsupply relations had started to change. Labor market liberalization also coincided with the removal of international trade barriers. Between 1975 and 2000 the share of exports in total Latin American gross domestic product (GDP) increased from ca. $7 \%$ to $20 \%$ and the share of imports rose at a comparable pace (Ocampo and Martin

\footnotetext{
${ }^{1}$ Demographic growth started to increase rapidly during the 1920 s and 1930 s in most LACs, reaching peak rates during the 1950s and 1960s (Thorp 1998: appendix table I.1, p. 313; Astorga et al. 2005; Frankema 2009a: pp. 151-155).

${ }^{2}$ For the region as a whole, rural population growth started to decline in the 1950 s and became virtually zero in the mid-1970s. Individual LACs, most notably Argentina and Uruguay, deviated from the aggregate pattern because they reached their peak growth rates already before 1914, due to the heavy influx of immigrants, see Frankema (2009b: Table 6.2, p. 154).
} 
2003: Fig. 2.3, p. 24). The share of industrial products in total exports also increased dramatically, from ca. $17 \%$ in 1960 to $66 \%$ in 1999 (Frankema and Smits 2005: Table 3, p. 185).

Third, Latin American labor market reforms left ample space for rent-seeking behavior. When the principles of collective wage bargaining and central wage setting during the ISI era were replaced by a decentralized system of wage bargaining (Arbache and Carneiro 1999), a trade-off emerged between wage demands and mass lay-offs. Some categories of employees remained protected by preferential treatments, however. Institutionalized monopolies or monopsonies were operating in the mining industries (including oil refineries), the financial and real estate sector and, not very surprisingly, the government sector (Galiani and Porto 2008). High-profit margins in protected sectors created incentives for rent sharing (Fontagne and Mirza 2007). If rents are high, it pays for workers to organize themselves in order to command a part of that margin. Disproportionate salaries of top managers can be made acceptable by using the wage bill as a lubricant for interpersonal loyalty, positive publicity, and self-enrichment.

The diagram presented in Fig. 1 visualizes the causal logic underlying the application of standard economic theories of wage inequality to the specific features of Latin American political and economic development in the twentieth century. We derive three hypotheses from this diagram which are to explain both, the differences of long-term wage inequality among LACs, as well as between the LACs and the other NWCs:

1. Similar to the NWCs, Latin American wage inequality has increased in the course of the twentieth century due to the skill-biased nature of international and domestic economic change.

2. The rise of Latin American wage inequality tended to be higher than in the NWCs however, because of the region's manifest inequalities in its education systems and the depth of the demographic transition in LACs, which in combination generated a vast oversupply of low-skilled labor.

3. The secular rise of wage inequality has followed a step-wise pattern in most LACs, because the effects of skill-biased technological change and globalization were mediated through political-institutional shocks. Intercountry differences in

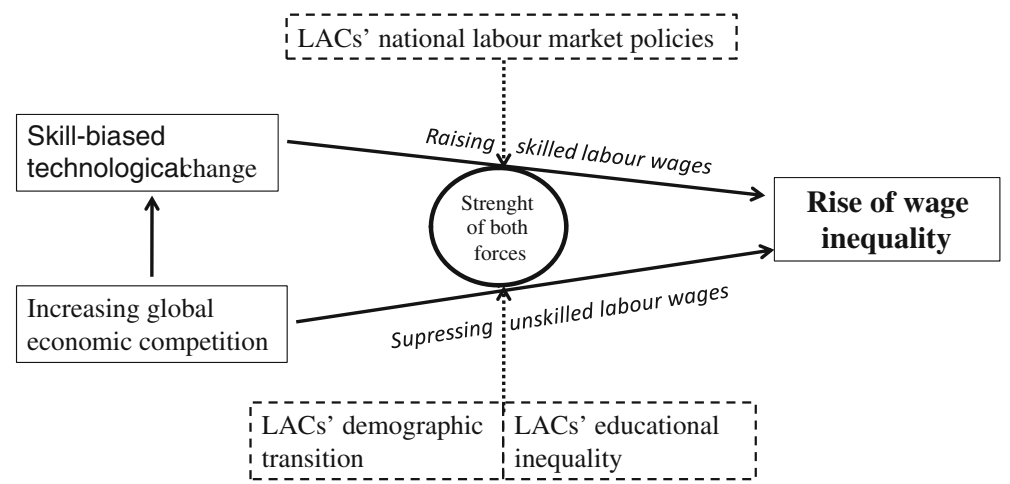

Fig. 1 Diagram presenting the hypothesized causal logic explaining the rise of wage inequality in twentieth century Latin America 
labor market policies and reforms can account for the different long-term wage inequality trends observed within Latin America.

\title{
Latin American Wage Inequality in Comparative Perspective, 1900-1950
}

\author{
Inter-industry Wage Inequality
}

Industrial survey and census data are a grateful source for wage inequality research. Industrial surveys cover a broad range of productive activities, varying largely in terms of capital intensity and technology-skill content. Inter-industry wage gaps are therefore likely to pick up a large part of the variation resulting from differences in labor productivity and technological sophistication (Berman et al. 1994, 1998). Since industrial enterprises produce tradable commodities, the effects of (de-)globalization should be visible in the development of inter-industry wage gaps as well. The classification of industrial sectors is relatively consistent over time, which facilitates temporal and interspatial comparisons. Many economists use industrial survey for this reason focusing on the post-war era (Berman et al. 1998; Berman and Machin 2000; Galbraith and Berner 2001; Galbraith and Kum 2002). However, industrial surveys are also available for various LACs in the pre-war era, which allows us to explore wage inequality trends in a more or less consistent framework over a longer period of time.

We use pre-war industrial surveys to compute (1) the average annual wage $\left(\mu_{x i}\right)$ for the industrial sector of country $(x)$, in year $(i)$; (2) the standard deviation of interindustry wage differentials $\left(\sigma_{x i}\right)$ over $n$ industries (or sectors); (3) the coefficient of variation $\left(\sigma_{x i} / \mu_{x i}\right)$; and (4) the Theil coefficient of inter-industry wage differentials. In contrast to the coefficient of variation, the Theil index not only includes the size of the wage gaps in measuring the dispersion of wages, but it also weighs the relative contribution of each sector in total income (Theil 1967, 1972). The Theil index is formally specified as:

$$
T=\sum_{i} w_{y}^{i} \log \left(w_{y}^{i} / w_{e}^{i}\right)
$$

where the Theil coefficient $T$ sums up over the log percentage share of sector $i$ in total value added or total labor income $\left(w_{y}^{i}\right)$, minus the log percentage share of sector $i$ in the total labor force $\left(w_{e}^{i}\right)$. Each sectors' Theil contribution is weighted for the percentage share of income of each sector $i$ in total income $\left(w_{y}^{i}\right)$.

Contrary to the post-war surveys, which have adopted the International Standard Industrial Classification (ISIC) classification with a predetermined number of predefined industries, the number of industrial sectors included in the pre-war surveys differs from country to country and, occasionally, within countries over time. To some extent, these differences reflect differences in the industrial sector structure between countries, but they may also reflect the adoption of different industrial classification schemes. Common industries such as foodstuffs, textiles, wood, paper, printing, chemicals, nonmetallic minerals (glass, stone, clay, ceramics, 
etc.), metals and machinery, or engineering are covered in almost all pre-war surveys, but for a subset of industries the aggregation levels differ.

The figures presented here only relate to industrial enterprises with formally registered employees, excluding owner-operated artisan shops. As the majority of observations are based on census data, the coverage of the industrial labor force is encouraging, but never complete. For instance, the 1910 benchmark for Chile includes approximately 35\% of the industrial labor force, the 1913 benchmark of Argentina ca. $63 \%$ and the 1920 benchmark of Brazil around $40 \%{ }^{3}$ For the post-war figures presented in the next section, the coverage is larger, usually ranging between $60 \%$ and $90 \%$. Differences in coverage can have an effect on the inequality comparison, but the bias is likely to be small because the Theil coefficient is based on sectoral averages.

Biases may also result from the aggregation of industries. Whenever sectoral averages disclose part of the wage variation, they will result in a downward bias of the computed inter-industry wage gap. Therefore, a low number of recorded sectors may produce an underestimation of comparative levels of wage inequality, although this is not necessarily the case. ${ }^{4}$ Hence, caution is required when interpreting the figures in Table 1 below, especially regarding Peru (1933) and Canada (1935), which are based on a survey including only nine sectors. Yet, for most countries, we have surveys with a fair amount of sectoral detail, covering between 15 and 22 industries.

Comparing the coefficients of variation of inter-industry wage gaps across countries suggests that inter-industry wage inequality was slightly higher in the LACs than in the four NWCs. The figures vary from 0.17 for Uruguay in 1930 to 0.28 for Colombia in 1938. In the four NWCs, the figures vary from 0.12 in Canada in 1935 (as noted above, this may be an underestimate) to 0.23 for New Zealand in 1906. Still, the overall level of wage dispersion in the LACs seems to have been relatively modest, especially when compared to the estimates of interindustry wage inequality for the late twentieth century in a large sample of LACs (see next section, Table 3). The highest recorded coefficient of variation, 0.28 for Colombia in 1938, relates to a maximum inter-industry wage gap of 1:2.5 between the paper and cardboard industry at the bottom and the engineering industry at the top end of the wage distribution. Moreover, the estimated Theil coefficients indicate that the overall differences between the LACs and the NWCs were virtually negligible.

Figure 2 presents the Theil coefficients for Argentina, Brazil, Chile, the USA, and Australia. Note that the number of sectors included in the surveys of these countries is higher in the three LACs than in the two NWCs, so if the comparison is biased due to differences in statistical record keeping the Theil coefficients of the USA and Australia are likely to be underestimated.

\footnotetext{
${ }^{3}$ Industrial labor force estimates from OXLAD, http://oxlad.qeh.ox.ac.uk/ (24-06-09); total numbers of wage and salary earners from the sources listed below Table 1.

${ }^{4}$ A lower number of sectors does not necessarily result in smaller wage gaps. For example, when calculating the level of wage inequality in the USA among the nine sectors listed in the Canadian census, the coefficient of variation is 0.20 , which is actually slightly higher than the 16 sector presented in Table 3 . It crucially depends on whether the sectors at the low and top end of the distribution are separately included or not. Combining sectors in the middle of the distribution can have an enlarging effect on the variation measured by the coefficient of variation.
} 
Table 1 Inter-industry labor income differentials in Latin America and the New World, 1900-1940

\begin{tabular}{|c|c|c|c|c|c|c|c|}
\hline & Year & Currency & $\begin{array}{l}\text { No. of } \\
\text { sectors }\end{array}$ & $\begin{array}{l}\text { Average } \\
\text { wage }\end{array}$ & SD & $\begin{array}{l}\text { Coefficient } \\
\text { of variation }\end{array}$ & $\begin{array}{l}\text { Theil } \\
\text { coefficient }\end{array}$ \\
\hline Argentina & 1913 & Peso $\mathrm{m} / \mathrm{n}$ & 20 & 1012 & 277 & 0.27 & 0.0066 \\
\hline Argentina & 1917 & Peso m/n & 13 & 3.31 & 0.74 & 0.22 & 0.0061 \\
\hline Argentina & 1937 & Peso $\mathrm{m} / \mathrm{n}$ & 22 & 1,513 & 383 & 0.24 & 0.0092 \\
\hline Brazil & 1920 & Real & 12 & 1,606 & 477 & 0.25 & 0.0085 \\
\hline Brazil & 1939 & Real & 20 & 2,469 & 604 & 0.24 & 0.0089 \\
\hline Chile & 1910 & Peso & 17 & 959 & 226 & 0.24 & 0.0077 \\
\hline Chile & 1925 & Peso & 17 & 2,499 & 602 & 0.23 & 0.0053 \\
\hline Colombia & 1938 & Peso & 15 & 1.49 & 0.42 & 0.28 & na \\
\hline Mexico & 1939 & Peso & 22 & 0.56 & 0.14 & 0.26 & na \\
\hline Peru & 1933 & Sol & 9 & 846 & 171 & 0.20 & na \\
\hline Uruguay & 1930 & Peso & 19 & 487 & 84 & 0.17 & 0.0042 \\
\hline US & 1900 & USD & 15 & 437 & 73 & 0.16 & 0.0061 \\
\hline US & 1914 & USD & 16 & 579 & 85 & 0.15 & 0.0059 \\
\hline US & 1925 & USD & 16 & 1,280 & 204 & 0.16 & 0.0059 \\
\hline US & 1935 & USD & 16 & 1,023 & 210 & 0.19 & 0.0082 \\
\hline Canada & 1910 & CAD & 15 & 419 & 84 & 0.19 & 0.0096 \\
\hline Canada & 1935 & CAD & 9 & 852 & 106 & 0.12 & 0.0044 \\
\hline Australia & 1912 & AUS Pound & 17 & 115 & 20 & 0.18 & 0.0136 \\
\hline Australia & 1923 & AUS Pound & 19 & 180 & 33 & 0.17 & 0.0091 \\
\hline Australia & 1935 & AUS Pound & 15 & 167 & 34 & 0.17 & 0.0096 \\
\hline New Zealand & 1906 & $\mathrm{NZ}$ pound & 18 & 79 & 18 & 0.23 & 0.0078 \\
\hline New Zealand & 1935 & NZ pound & 18 & 207 & 42 & 0.19 & 0.0132 \\
\hline
\end{tabular}

Argentina: Censo Comercal e Industrial de la Republica 1913, Boletin no. 20, Capital Federal, Minesterio de Agricultura, Buenos Aires 1914; Anuario Estadistico 1917, Boletin no. 42, Buenos Aires 1919; Estadistica Industrial de la Republica Argentina 1938, Buenos Aires 1940; Brazil: Recenseamento do Brazil 1920, Volume V, Rio de Janeiro 1927; Recenseamento do Brasil 1950, sinopse preliminar do censo industrial, Rio de Janeiro 1953; Chile: Estadistica Industrial de la Republica de Chile, 1910; Anuario Estadistico de la Republica de Chile, Vol. IX, 1925, Santiago de Chile 1927; Colombia, Mexico: ILO, Yearbook of Labour Statistics 1941, sixth year, Montreal 1942; Peru: Ministerio de Fomento, Las Industrias en el Peru 1936, Boletin del Cuerpo de Ingenieros de Minas del Peru, No. 114, Lima 1936; Uruguay: Censo Industrial de 1930, in: Revista de la Union Industrial de Uruguaya, ano 57, no. 135; USA: Abstract of the Twelfth Census of the US 1900, Washington 1902; Statistical Abstract of the US 1928, Washington 1928; Statistical Abstract of the US 1928, 50th number; Washington Statistical Abstract of the US 1938, 60th number, Washington; Canada: The Canada Yearbook 1912, Ottawa 1913; Dominion Bureau of Statistics, The Canada Yearbook 1938, Ottawa 1938; Australia: Manufacturing Industries in the Commonwealth 1912, Melbourne 1914; Production Bulletin No. 17, Summary of Australian Production Statistics for 1912-13 to 1922-23, Melbourne; Production Bulletin No. 30, Summary of Australian Production Statistics for 1925-26 to 1935-36, Canberra; New Zealand: The New Zealand Official Year-Book 1910, Nineteenth year of issue, Wellington, 1910; The New Zealand Official Year-Book 1938, Forty-Sixth issue, Wellington, 1938

The public utilities sector was deliberately removed from the estimation procedure to avoid a potential bias in comparison with surveys excluding this sector. Employees working in public utilities usually receive wages or salaries at the top end of the industrial wage distribution. In Argentina in 1917, Colombia 1938, and Mexico 1939 daily wages were recorded. Since there is no clear conjecture about the potential bias this may cause, nothing has been undertaken to correct for this. The estimates of Peru 1933 and Canada 1935 must be interpreted with care given the relatively low number of sectors included in the survey 


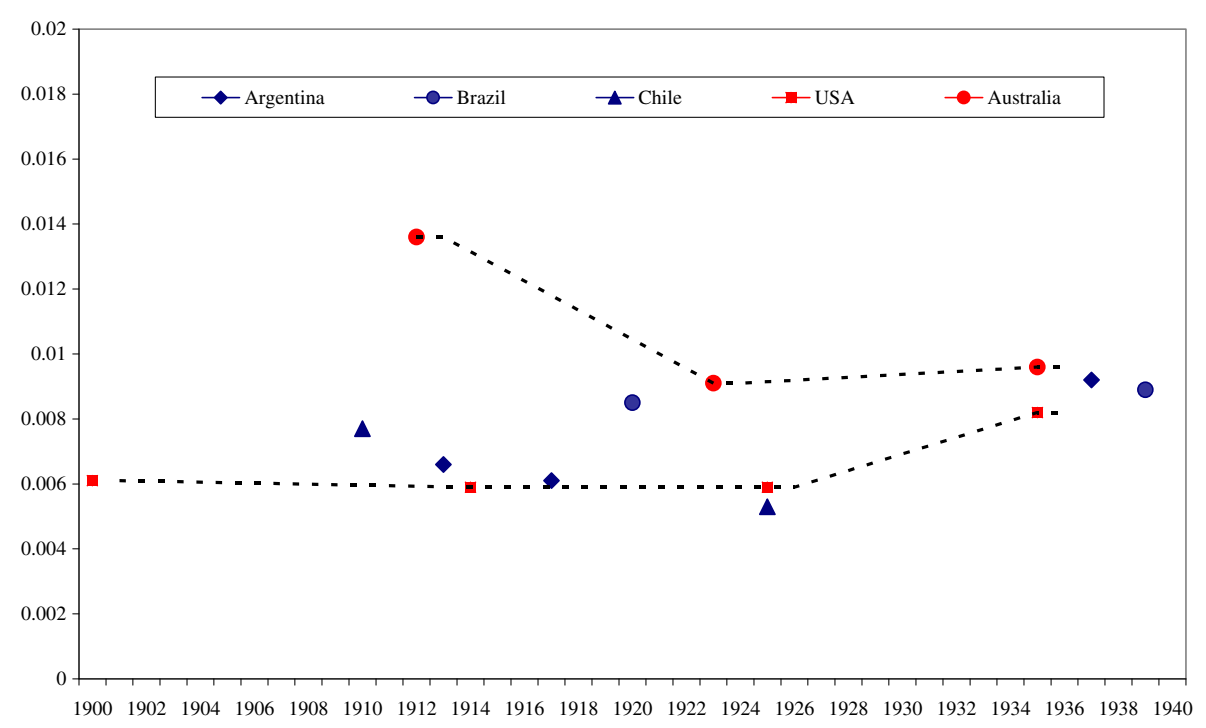

Fig. 2 Theil coefficients of inter-industry wage inequality in Argentina, Brazil, Chile, Australia, and the USA, 1900-1940. Sources: see Table 1

Figure 2 suggests that there were no large structural differences in the overall industrial wage distribution between Argentina, Brazil, and Chile on the one hand and the USA and Australia on the other hand. Hence, the higher coefficients of variation in the LACs were mainly caused by sectors at the outer end of the distribution with a relatively small contribution to total industrial labor income and a relatively small share in industrial employment.

\section{Intra-Industry Wage Inequality}

An analysis of inter-industry wage gaps may hide the major part of industrial wage inequality, if wage gaps within industries were much larger than across industries. Wage inequality would then have been driven by earning differences between unskilled and skilled workers, while the distribution of both groups of workers across industries was relatively equal. A limited number of pre-war industrial surveys give detailed information about the relative earnings of blue- and whitecollar workers. Despite the scattered nature of these observations, the ratios of the average white over blue-collar wage level can provide a crude impression of the comparative size of intra-industry wage gaps.

In Argentina in 1913, the "white-collar premium" was estimated at 1.71 in the industrial sector and 1.74 in trade and commerce (including wholesale and retail). ${ }^{5}$ In Chile in 1925, the average white-collar employee earned 3.01 times as much as the average blue-collar worker, which was notably higher, but in 1937 the Chilean white-collar premium was estimated to be 1.99, which is more in line with the level observed in Argentina. By comparison, for Canada in 1905 and 1925 we obtained a

\footnotetext{
${ }^{5}$ This figure is obtained from Minesterio de Agricultura, Censo Comercal e Industrial de la Republica 1913, Boletin no. 20 (Buenos Aires, 1914). The other figures are obtained from the sources listed at the bottom of Table 1 .
} 
white-collar premium of 1.85 and 1.90, respectively. In Australia, we record a whitecollar premium of 1.67 in 1923.

These figures suggest that Latin American wage gaps were modest across and within industries and not significantly higher than in the other NWCs. A more comprehensive view can be obtained from occupational wage surveys providing hourly wage levels in various construction occupations. These surveys are collected and published in the earliest editions of the ILO Yearbook of Labor Statistics and include information about wage levels in a number of major world cities, including some Latin American cities. Construction wages are widely used in economic historical studies to study long-term developments in real wages and skill premiums. Labor requirements for construction activities are characterized by a combination of low-skilled physical labor, such as carrying or preparing construction materials, and skilled labor with specifically designated tasks in the design and/or construction of buildings. For this reason, construction industry wages are considered to be quite suitable for comparative purposes (Phelps Brown and Hopkins 1957; Allen 2001; Clark 2007).

To calculate the average skill premium in the construction industry, we took the unweighted average of the hourly wage of carpenters and joiners, masons and bricklayers, structural iron workers, concrete workers, plumbers, painters, and electrical fitters and divided this number by the average wages of unskilled day laborers (peones) in construction. A peon, by definition, represents a worker without a clearly designated task in the construction process. Observations for a larger sample of cities are available from the mid-1930s to the mid-1950s. We split this period in two, 1935-1942 and 1946-1955, to exclude the (economically) most disruptive years of WWII (1943-45) and to accommodate differences in sample size. For the latter period, a substantial number of Asian and some African cities could be included. Figure $3 \mathrm{a}$ and $\mathrm{b}$ presents the results.

Skill premiums in the construction trade in the major Latin American cities turn out to have been only a little higher than in Melbourne, Sydney, and Wellington and more or less comparable with the North American cities New York, Los Angeles, and Toronto. Skill premiums in Latin American cities were notably smaller than in the majority of Asian cities. The variation in skill premiums across Asian cities appears to be larger as well. In Asia, the unweighted average is 2.06, with a variation coefficient of 0.18 and in Latin America (including four Caribbean cities: Havana, Kingston, San Juan, and Port of Spain) the unweighted average is 1.65 with a coefficient of variation of 0.14. Four Latin American cities in the period under consideration record a skill premium exceeding 2.0. These are Rio de Janeiro, La Paz, Bogota, and Caracas. The contrast with the few African cities in the sample underlines the conclusion that intra-industry wage gaps in Latin America appeared to be rather modest by international standards in the first half of the twentieth century.

Gender Wage Inequality

Whereas skill premiums mainly result from differences in workers' capabilities and responsibilities in production tasks, gender wage differentials contain a discriminatory component embedded in culturally determined views on the social status of women. In theory, gender wage discrimination occurs when females with comparable capacities, performing comparable tasks, receive lower rewards than 
a

1935-1942

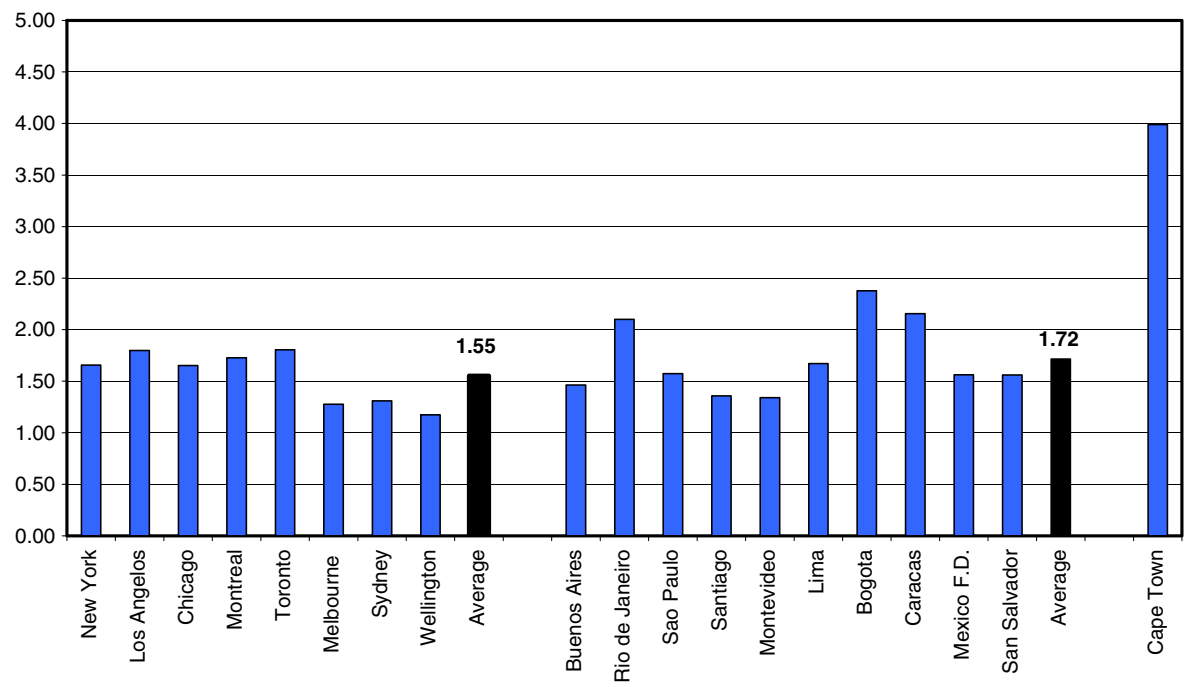

b

1946-1955

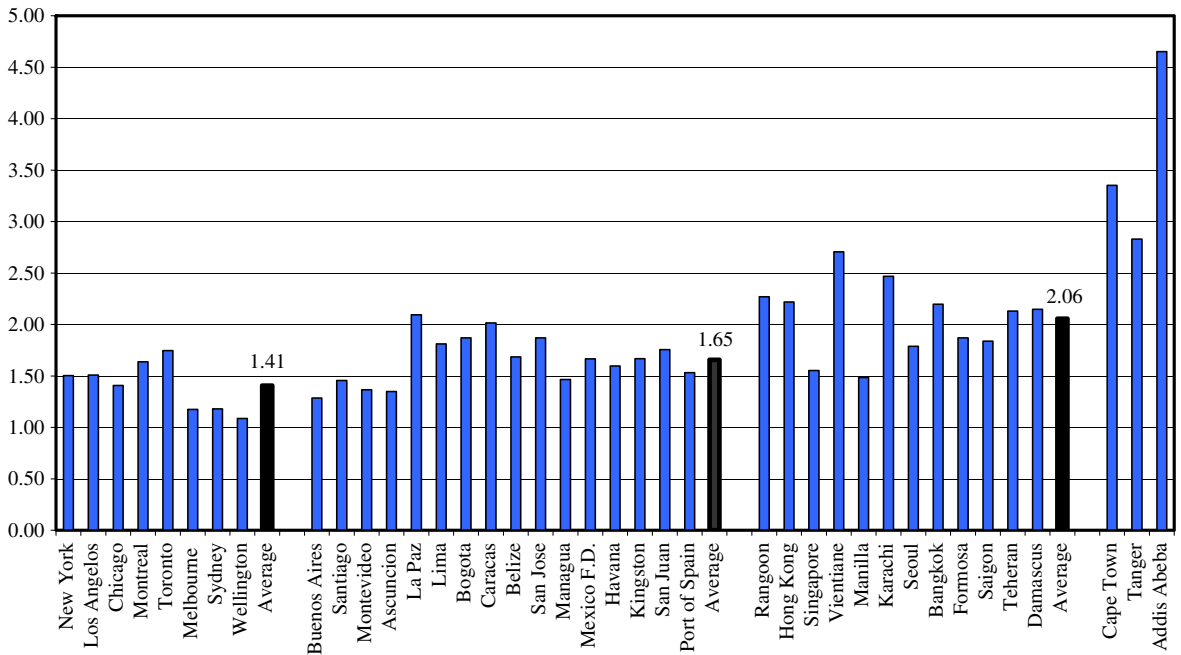

Fig. 3 a-b Skill premiums in the construction industry in a selection of major cities in the New World, Latin America, Asia, and Africa, 1935-1955. Source: ILO, Yearbook of Labour Statistics, various issues 19351960. Notes: In case more than one observation was for the designated period, an average has been included

their male counterparts. In practice, it is hard to isolate the discriminatory component in female wage setting because women often perform specifically designed tasks.

The figures presented in Table 2 can therefore only provide a crude impression of gender wage differentials and should be taken as upper-bound estimates. We compare the estimates of the LACs to the USA, Canada, Australia, and two large Asian countries, Japan and India, for which comparable data is available: all the male-female wage ratios presented are based on the average wages of male and female in the industrial sector as derived from industrial surveys or national wage statistics. 
Table 2 Gender wage differentials in the industrial sector in Latin America, the New World, Japan, and India, 1905-1940

Average wage male/female

\begin{tabular}{lll}
\hline Argentina (Buenos Aires) & 1917 & 1.64 \\
& 1940 & 1.90 \\
Brazil & 1920 & 1.68 \\
Chile & 1909 & 2.16 \\
Colombia & 1938 & 1.68 \\
Mexico & 1939 & 1.52 \\
Australia & 1912 & 2.41 \\
& 1938 & 1.87 \\
Canada & 1905 & 1.99 \\
& 1938 & 1.78 \\
New Zealand & 1906 & 2.10 \\
& 1938 & 1.72 \\
Japan & 1938 & 2.92 \\
India (Bombay) & 1934 & 3.21 \\
\hline
\end{tabular}

Argentina: Anuario Estadistico 1917, Boletin no. 42, Buenos Aires 1919; ILO, Yearbook of Labour Statistics 1941, sixth year, Montreal 1942; Brazil: Recenseamento do Brazil 1920, Volume V, Rio de Janeiro 1927; Chile: Estadistica Industrial de la Republica de Chile, 1910; Colombia, Mexico: ILO, Yearbook of Labour Statistics 1941, sixth year, Montreal 1942; Canada: The Canada Yearbook 1912, Ottawa 1913; Dominion Bureau of Statistics, The Canada Yearbook 1938, Ottawa 1938; Australia: Manufacturing Industries in the Commonwealth 1912, Melbourne 1914; ILO, Yearbook of Labour Statistics 1941, sixth year, Montreal 1942 New Zealand: The New Zealand Official Year-Book 1910, Nineteenth year of issue, Wellington, 1910; The New Zealand Official Year-Book 1938, Forty-Sixth issue, Wellington, 1938; Japan: Bank of Japan (1962) Historical Statistics of the Japanese Economy, Tokyo; India: Labour Office, Government of Bombay, General Wage Census, Part 1, Perennial Factories (May 1934), Bombay 1935

Gender wage gaps in the five recorded LACs range from 2.16 in Chile (1910) to 1.52 in Mexico (1939). These figures compare to 2.41 in Australia (1912) and 1.72 in New Zealand (1938). They suggest that between 1905 and 1940, gender wage differentials in Latin America were somewhat lower than in the NWCs and notably lower than in Japan and India in the 1930s, although the empirical evidence is rather thin. There is additional support, however, for the view that gender wage gaps were comparatively modest in Latin America. Camps et al. argue that gender wage gaps in the urban sectors of the economy in Latin America during the second globalization era (this study covers the period 1975-2000) were not only smaller, but also declined more rapidly than in a sample of East Asian countries (Camps et al. 2006). According to Camps et al., the relatively modest gender gaps in human capital formation in Latin America are the most important explanation for the observed difference. Empirical evidence of gender inequality in education for the late nineteenth and early twentieth century also demonstrates that the gender gap in LACs was comparatively small.

Table 3 presents female primary school enrolment shares for six LACs, three NWCs, and four Asian countries. The data are derived from Lindert (2004: Table 
Table 3 The percentage share of female in total primary school enrolment in Latin America, the New World, and Asia, 18801902

Source: All data derived from Lindert (2004: Table 5.2, p. 95)

\begin{tabular}{|c|c|c|}
\hline & & $\begin{array}{l}\% \text { share female of } \\
\text { primary enrolled }\end{array}$ \\
\hline Argentina & 1900 & 46.1 \\
\hline Chile & 1900 & 51.6 \\
\hline Uruguay & $1890-04$ & 45.1 \\
\hline El Salvador & 1893 & 43.4 \\
\hline Guatemala & $1890-04$ & 32.8 \\
\hline Cuba & $1901-02$ & 46.8 \\
\hline Australia (3 states) & $1890-04$ & 48.3 \\
\hline Canada (7 provinces) & 1901 & 49.0 \\
\hline US & 1880 & 48.5 \\
\hline Japan & 1892 & 30.9 \\
\hline India: Bombay & $1900-01$ & 14.2 \\
\hline Punjab & $1900-01$ & 7.6 \\
\hline Madras & 1899-00 & 6.2 \\
\hline Mysore & $1900-01$ & 17.8 \\
\hline Burma & $1900-01$ & 7.8 \\
\hline Ceylon & 1898 & 5.0 \\
\hline
\end{tabular}

5.2, p. 95). The enrolment share of female students in primary education indicates that although there certainly existed a gap between boys and girls in Latin American primary schools, this gap was comparatively modest and around the mid-twentieth century it had been virtually completely resolved in most LACs (Frankema 2009a: Table 4.2, p.94-5). In many LACs, the female enrolment shares were comparable to those in the USA, Canada, and Australia.

More remarkable is the contrast with the Asian countries. Even Guatemala, one of the least modernized LACs, recorded a female enrolment share $(32.8 \%)$ higher than Japan (30.9\%), arguably the most modernized East Asian country of the late nineteenth century. And compared to some of the regions of the Indian subcontinent, where the female share remained below $10 \%$, gender inequality in primary education in Latin America appears to be very modest. Hence, the Latin American-Asian contrast in educational gender inequality seems to be reflected in the differences in gender wage inequality as revealed in Table 3.

In sum, all three analytical perspectives indicate that Latin American wage inequality has been comparatively modest by international standards during the first half of the twentieth century, despite some notable intraregional differences. The next section will show that this Latin American pattern of "modest" wage inequality changed dramatically during the second half of the twentieth century and, in some countries, also changed rather abruptly.

\section{The Post-War Rise of Latin American Wage Inequality, 1950-2000}

This section explores the long-term trend in inter-industry wage distribution by linking the scattered evidence of the first half of the twentieth century to the more 
consistent time series that can be obtained for the post-war period. As argued above, there exists no single wage inequality measure that captures developments in the total wage distribution, but the inter-industry wage inequality indicator is one of the most comprehensive measures available. Reflecting changes in the skill and technology composition of industrial sectors, this measure is likely to pick up the effects of skill-biased structural changes in the economy (Galbraith and Berner 2001). Sectoral data on employment, wages, and value added have been collected in a consistent framework of sector classifications from the 1950s onwards. Our post1950 estimates of inter-industry wage inequality are based on the ISIC of economic activities, including 20 manufacturing branches, as presented in the UN Yearbook of Industrial Statistics. ${ }^{6}$ Since ISIC has been revised two times between 1950 and 2000, we show the results for the ISIC 1 and 2 classifications. $^{7}$

Table 4 presents the inter-industry wage inequality estimates for 15 LACs in 6 consecutive periods during the twentieth century and compares these to the figures for the USA, Canada, and Australia. Only for Argentina, Brazil, and Chile we were able to find sufficiently reliable data for the earlier periods. We chose 1974 (the oil crises) and 1989 (endpoint of the "lost decade") as benchmark years and excluded the 1940 s due to lack of data.

Table 4 shows that the rise of wage inequality was a widely shared Latin American phenomenon. In all 15 LACs, there was a net increase between 1950 and 2000. The unweighted regional average of the Theil coefficient of inter-industry wage inequality increased from 0.014 (1950-73) to 0.019 (1974-1989) and further, to 0.031 in the $1990 \mathrm{~s}$.

The magnitude and timing of the increase differed substantially across countries, however. The rise in Colombia and Mexico, for instance, was much smaller than in Panama or Peru. In some LACs, we observe a trend break in the 1960s (Costa Rica and Panama), but in the majority of cases in the 1970s or early 1980s (Argentina, Bolivia, Chile, Dominican Republic, Ecuador, Guatemala, and Peru).

A global comparative perspective reveals that the dramatic upward trend that can be observed in the LACs did not occur in the three NWCs. In Australia and Canada, the rise of the Theil coefficient was gradual and modest. A slight downward trend can be discerned from the early twentieth century onwards until the mid-1970s, when inter-industry wage differentials started to widen. In the USA, a more pronounced rise can be noted during the 1970 s. Considering that the three NWCs entered a phase of post-industrial economic development during the last decades of the twentieth century, it seems justified to conclude that the peak level of industrial wage inequality has been much higher in Latin America than in North America.

\footnotetext{
${ }^{6}$ The first compilation of national industrial statistics by the United Nations appeared in 1967, as The Growth of World Industry, 1953-1965, National Tables, New York. In 1975, this changed into UN, Yearbook of Industrial Statistics 1975, New York, and since 1993 the statistic has been published by the United Nations Industrial Development Organization (UNIDO) under the title, International Yearbook of Industrial Statistics, Vienna. See http://www.unido.org/index.php?id=4879 (24-06-2009).

${ }^{7}$ To check the potential bias of the conversion of classifications we also estimated the wage inequality trends on the basis of the ISIC revision 3. Although the estimated levels are generally higher, the long terms trends hardly differed from the ISIC 1 and 2 classifications.
} 
Table 4 Theil coefficient of inter-industry wage inequality in Latin America, 1900-2000

\begin{tabular}{|c|c|c|c|c|c|c|c|}
\hline & $1900-1920$ & 1921-1940 & $\begin{array}{l}\text { 1950-1973 } \\
\text { ISIC } 1\end{array}$ & $\begin{array}{l}\text { 1974-1989 } \\
\text { ISIC } 1\end{array}$ & $\begin{array}{l}\text { 1974-1989 } \\
\text { ISIC } 2\end{array}$ & $\begin{array}{l}\text { 1990-2000 } \\
\text { ISIC } 1\end{array}$ & $\begin{array}{l}\text { 1990-2000 } \\
\text { ISIC } 2\end{array}$ \\
\hline Argentina & 0.006 & 0.009 & 0.006 & 0.014 & 0.015 & 0.022 & 0.023 \\
\hline Bolivia & & & 0.019 & 0.023 & 0.025 & 0.038 & 0.040 \\
\hline Brazil & 0.009 & 0.009 & 0.013 & 0.027 & 0.027 & 0.047 & 0.048 \\
\hline Chile & 0.008 & 0.005 & 0.014 & 0.025 & 0.026 & 0.027 & 0.029 \\
\hline Colombia & & & 0.020 & 0.015 & 0.017 & 0.018 & 0.019 \\
\hline Costa Rica & & & 0.008 & 0.015 & 0.015 & 0.018 & 0.019 \\
\hline $\begin{array}{r}\text { Dominican } \\
\text { Republic }\end{array}$ & & & 0.021 & 0.031 & 0.031 & na & na \\
\hline Ecuador & & & 0.016 & 0.012 & 0.014 & 0.037 & 0.039 \\
\hline El Salvador & & & 0.013 & 0.015 & 0.016 & 0.028 & 0.030 \\
\hline Guatemala & & & 0.021 & 0.030 & 0.032 & 0.034 & 0.046 \\
\hline Mexico & & & 0.010 & 0.010 & 0.011 & 0.017 & 0.018 \\
\hline Panama & & & 0.007 & 0.022 & 0.023 & 0.040 & 0.041 \\
\hline Peru & & & 0.012 & 0.017 & 0.018 & 0.047 & 0.048 \\
\hline Uruguay & & & 0.012 & 0.015 & 0.016 & 0.030 & 0.031 \\
\hline Venezuela & & & 0.013 & 0.013 & 0.014 & 0.032 & 0.035 \\
\hline $\begin{array}{l}\text { Latin America } \\
\text { average }\end{array}$ & 0.007 & 0.008 & 0.014 & 0.019 & 0.020 & 0.031 & 0.033 \\
\hline Australia & 0.014 & 0.009 & 0.002 & 0.003 & 0.003 & 0.007 & 0.008 \\
\hline Canada & 0.010 & 0.005 & 0.007 & 0.008 & 0.008 & 0.009 & 0.010 \\
\hline USA & 0.006 & 0.007 & 0.007 & 0.013 & 0.014 & 0.010 & 0.011 \\
\hline $\begin{array}{l}\text { New World } \\
\text { average }\end{array}$ & 0.010 & 0.007 & 0.006 & 0.008 & 0.009 & 0.009 & 0.010 \\
\hline
\end{tabular}

See“Latin American Wage Inequality in Comparative Perspective, 1900-1950" section for pre-1950 data. Post-1950 data are taken from various issues of the United Nations, The Growth of World Industry, National Tables, New York (1953-1974); United Nations, Yearbook of Industrial Statistics, New York (1975-1992); UNIDO, International Yearbook of Industrial Statistics, Vienna (1993-2005)

In case of more than one observation per period, the average is included

\section{Explaining Long-Term Wage Inequality Trends in Latin America}

We have seen that during the first half of the twentieth century, wage inequality in the LACs did not differ markedly from the NWCs. The gap between rich and poor was primarily a gap between capital owners and wage laborers. The manufacturing sector was dominated by small workshops where technology-skill complementarities and opportunities for rent sharing by the higher management were comparatively small. Moreover, the supply of unskilled labor was far less abundant in this period. This changed in the course of the twentieth century. The share of wages and salaries in the income portfolio of the higher social classes rose and the progress in industrial technology created ample opportunities for job diversification, growing productivity differentials, and increasing gaps in labor remunerations. The growing impact of wage inequality in overall income inequality has been documented for many industrial countries (Atkinson and Piketty 2007). 
The key question, however, is why the post-war rise in inter-industry wage inequality was so much more pronounced in Latin America? To answer this question, it is useful to look in greater detail at three larger Latin American economies for which we have particularly good long-term series, i.e., Argentina, Brazil, and Chile. These three cases are instructive for two more reasons. First, all three countries experienced a major phase of industrialization during the twentieth century which has fundamentally transformed the structure of their economies and the composition of their export packages. Second, all three countries have experienced notably different patterns of long-term wage inequality development which helps to shed more light on the underlying determinants of some of the intraregional differences noted in the previous section. The theoretical framework of "Theories and Hypotheses of Latin American Wage Inequality" section is adopted to examine to which extent plain economic theory can account for these intraregional differences and to which extent political-institutional shocks need to be incorporated in order to understand critical junctures in the long-term trend.

Figure 4 shows that all three LACs experienced a spectacular rise in industrial labor income differentials during the post-war era when compared to the NWCs and their own pre-war levels, but the magnitude and timing of the trend breaks differs. In Argentina, we observe a modest increase of wage inequality between 1910 and the mid-1930s, followed by a marked decline during the 1940s and 1950s, and a very steep increase of wage inequality from the mid-1970s onwards, continuing until the end of the century. ${ }^{8}$ In Brazil, we observe a nearly continuous increase from the 1940s onwards, with a minor interruption in the 1970s. In Chile, we also see a longterm rise but with a steep decline between 1964 and 1973.

The Argentinean trend breaks in the mid-1940s and mid-1970s coincide with two major landmarks in its political history: the beginning and end of Peronismo. Wage regulation schemes became part of government policy during the 1940s, when Perón launched a radical reform agenda including real wage increases, a reduction of working hours, paid vacation, and the implementation of an extensive social security system. Comprehensive wage regulation programs remained in place until the mid1970 s, testifying to the longstanding commitment of various Argentine governments to ISI policies (Rock 1987: 262-6; Romero 2002: 65-9). State subsidies and trade tariffs shielded the industrial sector from foreign competition and enabled a system of wage setting that circumvented international market pressures. Not only were industrial wage gaps small, the labor share in national income was also comparatively high, between $50 \%$ and $60 \%$ of total GDP (Beccaria 1991; Galiani and Gerchunoff 2003: 152; Frankema 2010).

The military coup of 1976 heralded a decisive reorientation of socioeconomic policy inspired by neoliberal economic ideology. Confronted with inflation rates of nearly $600 \%$, Martínez de Hoz, the minister of economy in the Vidéla administration, decreed a freeze on wages. After several failed attempts, inflation was eventually suppressed but at the expense of a dramatic fall in the purchasing power of ordinary wage earners. A wide array of economic reform schemes, including privatization of state enterprises, mass lay-offs, a reduction of trade

\footnotetext{
${ }^{8}$ The exact timing of the first phase remains uncertain due to a lack of intermediate observations between 1917 and 1935.
} 


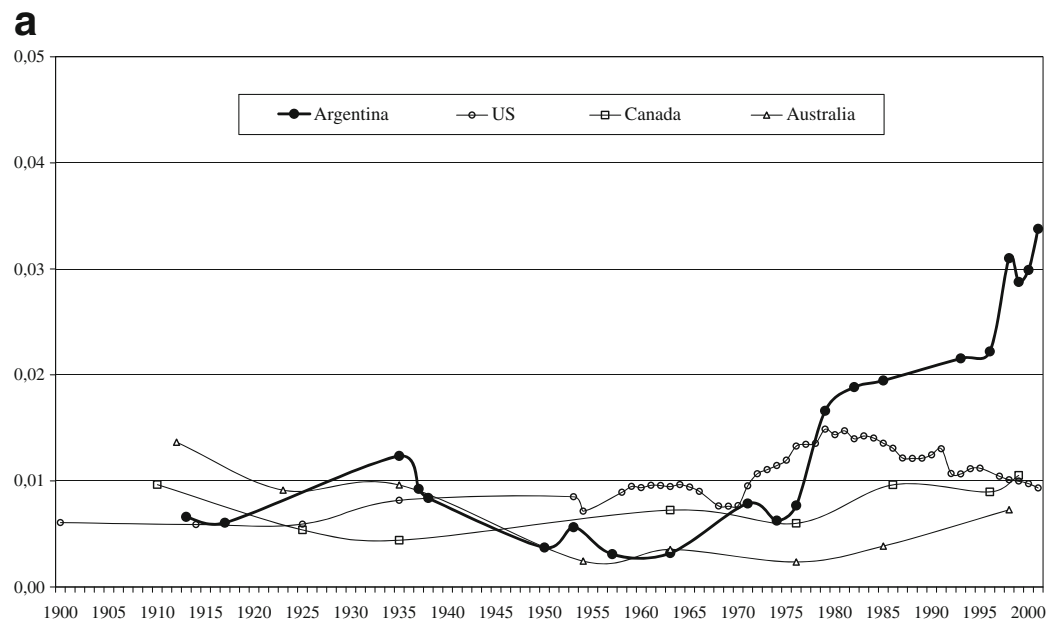

b

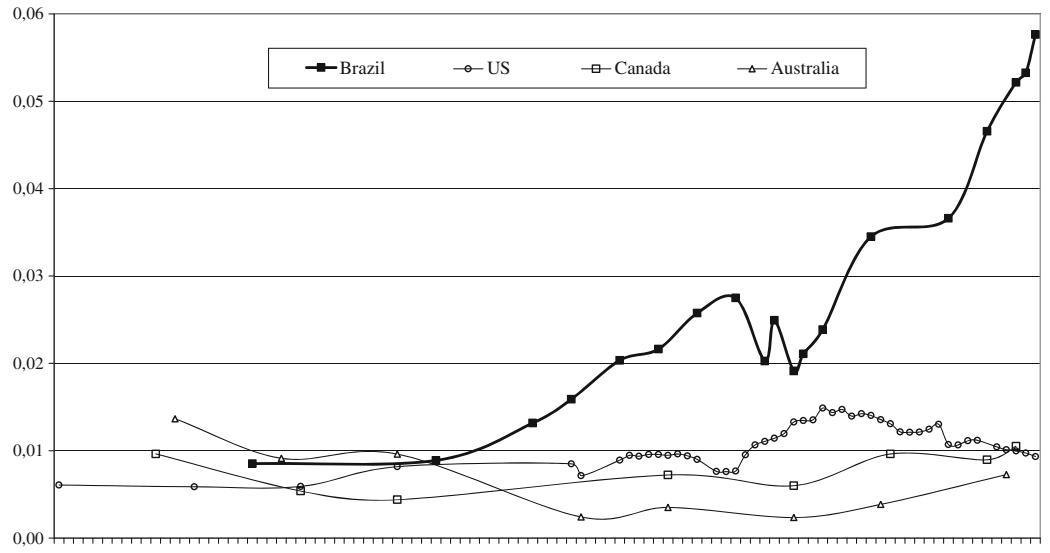
$\begin{array}{lllllllllllllllllllll}1900 & 1905 & 1910 & 1915 & 1920 & 1925 & 1930 & 1935 & 1940 & 1945 & 1950 & 1955 & 1960 & 1965 & 1970 & 1975 & 1980 & 1985 & 1990 & 1995 & 2000\end{array}$

C

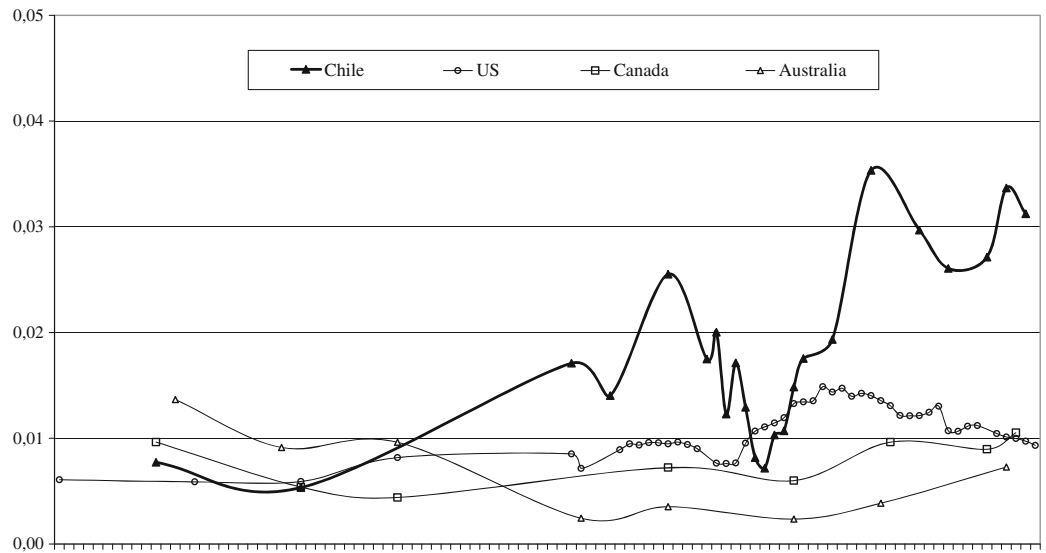
$\begin{array}{lllllllllllllllllllll}1900 & 1905 & 1910 & 1915 & 1920 & 1925 & 1930 & 1935 & 1940 & 1945 & 1950 & 1955 & 1960 & 1965 & 1970 & 1975 & 1980 & 1985 & 1990 & 1995 & 2000\end{array}$ 
Fig. 4 a-c Theil coefficients of inter-industry wage inequality in Argentina, Brazil, Chile versus Australia, Canada, and the USA, 1900-2000. Sources: Various issues of United Nations, The Growth of World Industry, National Tables, New York (1953-1974); United Nations, Yearbook of Industrial Statistics, New York (1975-1992); UNIDO, International Yearbook of Industrial Statistics, Vienna (1993-2005)

barriers, and the introduction of a new currency, made the income position of wage earners extremely insecure (Lewis 1990: 460-9).

The major long-run changes in Argentina's wage inequality can thus be explained by political regime changes altering the nature of government wage regulation (Altimir 1986; Altimir and Beccaria 1999). But changing government policies cannot fully explain the continuous worsening of the wage distribution after the mid1970s. In their attempt to evaluate the impact of changing market forces, Galiani and Sanguinetti separated industries witnessing import penetration deepening from those that remained largely unaffected by trade liberalization during the 1990s. They concluded that $15 \%$ of the additional increase of the within-sector skill premium in Argentina can be attributed to trade liberalization (Galiani and Sanguinetti 2003).

Waisgrais has argued that educational inequality is the single most important explanatory variable for Argentinean wage differentials in the 1980s and 1990s (Waisgras 2003: 39-41). However, with shares ranging between 14\% and 23\%, the contribution of human capital differentials still appears modest. Comparable studies of other LACs produce estimates in the range of 20-40\% (Cárdenas and Bernal 1998; Chanduví and Díaz 1998; Ferreira and Litchfield 1998). These studies confirm that skill-biased technological change and globalization have been important in driving up Argentinean wage gaps in the last quarter of the twentieth century, but they also leave room for an explanation that emphasizes sector-biased opportunities of rent sharing. Indeed, after controlling for schooling, age, and sex differences, the combined effects of production scale and type of productive activity (which are both highly sector-specific) was found to account for 23\% of Argentinean wage inequality (Waisgras 2003: 39).

In Chile, the major trend breaks in wage inequality can also be attributed to political regime changes. During the conservative government of Alessandri (1958-1964), interindustry wage differentials increased under influence of higher payments in the metal and chemical sectors, which were dominated by the copper and nitrate enterprises. The electoral victory of the Christian Democratic Party in 1964 redefined the political balance (Collier and Sater 2004: 308). Frei nationalized Chile's copper industry, which until then was controlled by American companies. One of the results of the nationalization program was a reduction of wage gaps between copper-related industries and other industries. This reduction was part of a more comprehensive policy to reduce the wage gaps between the private and the public sector and expand social benefits to previously neglected groups like the landless peasants and urban poor.

Urban wages converged during the Frei era, but the steepest decline of the Theil coefficient followed upon the installation of Allende's socialist government in September 1970. Allende declared a large-scale nationalization of industries, a massive expansion of public works, and a "Keynesian" impulse to consumption and economic growth. Average wages rose with circa 55\%, overcompensating an inflation rate of 33\% (Wright 1982: 344). In line with his socialist principles, bluecollar workers in low-paying industries benefitted most from the new wage regulations. The Theil coefficient dropped from 0.017 to 0.007 between 1970 and 
1973. The ratio of white- to blue-collar wages also declined from 2.81 in 1970 to 2.17 in 1973.

The economic policies of Frei and Allende can be placed in a longer tradition of welfare state expansion which had already begun in the 1920s. Levels of social spending in Chile were about twice as high as in the average LAC in the post-war era and comparable to many Organisation for Economic Co-operation and Development (OECD) countries, reaching a peak level of ca. $42 \%$ of total fiscal expenditure in the early 1970s. As a percentage share of GDP, social public expenditure increased from $2.1 \%$ in 1925 to $25.8 \%$ in 1972 (Arellano 1985: 404-5). With the growing political influence of labor unions, new types of benefits were implemented in the sphere of housing, health insurance, family and maternity allowances, unemployment pay, and dismissal indemnities.

These social policies did not lead to an uninterrupted decline of wage inequality. Arellano argues that during the 1930s, 1940s, and 1950s, the trade unions became increasingly middle-class oriented: bargaining in favor of their contributors, but neglecting the increasing income security gap with non-unionized or less powerful union workers, resulting in "a rather unequal structure of benefits and contributions" (Arellano 1985: 409).

The military coup of 1973 marked the key turning point in Chilean welfare policies. Pinochet launched a radical program of market reforms and a strong repression of labor unions. The Theil coefficient rose to unprecedented levels in the decade following 1973 and reached a temporary peak in the mid-1980s. In particular, the workers in the chemical, metal, and petroleum industries started to earn much better than workers in other sectors. In 1984, the white-collar premium had gone up from 2.17 in 1973 to 3.45 . Around the mid-1980s, inter-industry wage gaps were more or less stabilized at a structurally higher level.

After Pinochet's resignation and the return to democratic government, there was a strong political commitment to revitalize labor rights and amend the social inequalities which had prevailed for almost two decades of dictatorial rule. The center-left Concertatión de Partidos por la Democracia advocated the redistribution of income and wealth as one of its top priorities. Figure $4 \mathrm{c}$ indicates, however, that wage gaps did not diminish during the 1990s. This raises support for the argument of Barrett that the labor reforms enacted by the Aylwin administration were "largely cosmetic changes that helped to institutionalise the profound power imbalance in capital-labor relations and the subordination of labor policy to the demands of the economic model" (Barrett 2001: 568). Frank states in a similar fashion that "the economic model created by Pinochet's Chicago Boys has been internalized by many of the Concertation parties and their members" (Frank 2002: 63).

The case of Chile demonstrates that even in an LAC with a historical commitment to welfare policies, liberalization programs have produced levels of wage inequality which were far higher than in the NWCs. Although the exact reasons need to be researched in greater detail than we do here, there is little doubt that Chile's high educational inequality has aggravated the inequality impact of skill-biased changes in international and domestic economic conditions (Birdsall et al. 1997; Frankema 2008).

Having said this, wage inequality in Argentina and Chile never reached levels comparable to Brazil. In fact, Brazilian levels of inter-industry wage inequality grew 
larger than in any other LAC, with the possible exception of Peru. Wages started to diverge in the 1940s and only temporary converged during the 1970s. Table 5 shows the Theil coefficient of inter-industry labor productivity differentials (first column), together with the Theil coefficient of wage inequality (second column) and the ratio of the average nominal industrial wage to the legal nominal minimum wage (third column) between 1949 and 1999 .

Table 5 demonstrates that productivity gaps diverged strongly and that the average nominal industrial wage rose far above the official minimum wage in the second half of the twentieth century (the ratio rose from 1.4 in 1949 to 6.9 in 1996). Both developments reflect the expanding scope for increasing wage gaps in the industrial sector. Rising productivity differentials also reflect the extreme inequalities in the Brazilian education system (Park et al. 1996; Birdsall et al. 1997; Brown 2002; Frankema 2008, 2009b), which drove up the skill premium to unprecedented heights in the wake of skill-biased technological change and globalization.

Langoni has made a strong case for the poor state of education as the main determinant of the steep rise of Brazilian inequality in the 1960s. He argued that the rapid economic and technological development of Brazil raised the demand for scarce skilled labor, hence increasing the skill premium, while an oversupply of loweducated workers tied wages at the bottom of the wage distribution to subsistence levels (Langoni 1973; Langoni 1974). His argument is not undisputed however, as Bonelli and Ramos point out that during the 1980s, when Brazil's economy stagnated and experienced a decade of zero growth, inequality kept rising. According to these authors, it is difficult to see how skill-biased technological change induced a further widening of wage and income gaps during the crises years (Bonelli and Ramos 1992: 6-7).

Again, this puzzle cannot be solved without paying attention to changes in government policy. Since the inception of collective wage bargaining under the Vargas administration and the implementation of the general Labor Code (Consolidação das Leis do Trabalho) in 1943, trade unions were legally recognized

Table 5 Wage inequality and productivity differentials in Brazilian industry, 1949-1999

For the data used to calculate the Theil coefficient of the productivity and wage distribution and the average industrial wage, see Fig. 3b. The official minimum wage rates were obtained from IBGE, Anuário Estatístico do Brasil (various issues 19502000). All hourly minimum wage rates were multiplied with 2,400 h (300 working days of

$8 \mathrm{~h})$ to obtain a consistent benchmark for a comparison with annual industrial wages

\begin{tabular}{lccc}
\hline & $\begin{array}{c}\text { Theil coefficient } \\
\text { labor productivity } \\
\text { distribution }\end{array}$ & $\begin{array}{c}\text { Theil coefficient } \\
\text { wage distribution }\end{array}$ & $\begin{array}{l}\text { Average industrial } \\
\text { wage/Official } \\
\text { minimum wage }\end{array}$ \\
\hline 1949 & 0.0185 & 0.0132 & 1.4 \\
1953 & 0.0191 & 0.0159 & 1.8 \\
1958 & 0.0155 & 0.0204 & 2.1 \\
1962 & 0.0326 & 0.0216 & 2.3 \\
1966 & 0.0197 & 0.0257 & 3.1 \\
1970 & 0.0408 & 0.0275 & 2.5 \\
1974 & 0.0432 & 0.0249 & 3.5 \\
1977 & 0.0406 & 0.0211 & 3.3 \\
1984 & 0.0567 & 0.0345 & 3.6 \\
1992 & na & 0.0366 & 4.0 \\
1996 & 0.0784 & 0.0466 & 6.9 \\
1999 & 0.1264 & 0.0522 & 6.5 \\
\hline & & & \\
\hline
\end{tabular}


negotiating partners, but with limited rights. The ideology of Integralismo, which gained influence during the Vargas era (1930-54), promoted the transcendence of traditional class conflicts in the name of national economic interests. In this ideology socioeconomic inequality was regarded as a fundamental characteristic of an organic and dynamic society (Levine 1999: 94-119).

Contrary to the coups in Argentina (1976) and Chile (1973), the military coup of 1964 in Brazil reinforced prevalent wage policies. The military dictatorship (19641985) strengthened state control on wage bargaining procedures and continued to suppress the political role of trade unions: state-enforced wage programs were extended to all registered workers, lay-off costs were reduced, and political strikes were prohibited. By strengthening the authoritarian character of the Labor Code, the military government tried to control the vicious cycle of price hikes by a systematic under-indexation of wages (Carneiro 1998: 140-1). Many scholars have seen the adoption of different wage indexation schemes for different sectors as the major determinant of increasing wage gaps in this period (Macedo 1977; Bacha and Taylor 1978; Wells and Drobny 1982).

Figure $4 \mathrm{~b}$ shows that wage inequality increased during periods of high inflation, such as the years 1959-1966, 1978-1985, and 1990-1993. Baer has estimated that during the years 1983-1987, minimum wage earners experienced a decline in purchasing power of up to $10 \%$ or more as a result of incomplete indexation (Baer 2001: 105-6 and 470-1). Policy responses to inflation can also partly explain the temporary convergence of wages during the 1970s, when economic conditions were relatively favorable. Inflation rates remained comparatively moderate until 1978 (hovering between $15 \%$ and $45 \%$ ) which facilitated a rise in real minimum wages. The estimated gains were about $15 \%$ in São Paulo and $8 \%$ in Rio de Janeiro between 1970 and 1978 (Baer 2001: 105-6).

To which extent indexation policies were determined by political interests or by plain market forces is still not very well understood. Various scholars have argued that the Brazilian industrial sector offers ample opportunities for rent sharing. Sectorally organized trade unions can negotiate higher wages depending on their amount of political influence. This can explain part of the excessive earnings generated in the oil-related industry in Brazil (Colistete 2007). Arbache and Carneiro also argue that the differences in the bargaining power of trade unions were substantial (Arbache and Carneiro 1999). Carneiro reports evidence of "pervasive" rent sharing in the late 1980s and early 1990s in industries with high monopolistic market power such as the petrochemical industry (Carneiro 1998: 150-1).

In sum, the different wage inequality trends in Argentina, Chile, and Brazil do not seem to be a matter of more or less government intervention in the labor market, but rather of fundamental differences in the design and objectives of government wage regulation programs. The administrations of Perón, Frei, and Allende gave higher priority to the moderation of wage gaps than any of the post-war Brazilian governments ever did. This conclusion strengthens the overall argument of this study, namely that standard economic theory fails to explain wage inequality trends in Latin America because of its neglect of political responses to changing economic conditions. This is not to say that economic change was factor neutral in Latin America, on the contrary. The surplus of wage inequality in comparison to the NWCs at the end of the twentieth century testifies to the skill-biased content of 
structural and technological changes in economies characterized by high levels of human capital inequality.

\section{From Wage Inequality to Income Inequality}

What has been the impact of rising wage inequality on the overall interpersonal income distribution in LACs? The results presented above leave little doubt that wage inequality in Latin America, as in most other industrialized economies, has become a more important component of total income inequality, especially during the last quarter of the twentieth century (Atkinson and Piketty 2007). To obtain an impression of the potential contribution of wage inequality, we can compute Theil coefficients of gross household income inequality for benchmark years around 1960 and 2000 and compare these to the Theil coefficients of inter-industry wage inequality reported in this study. Table 6 presents the figures for Argentina, Brazil, and Chile.

Because the Theil index is a decomposable inequality indicator, we can derive some educated guesses form the data about the share of total labor income inequality in total interpersonal income inequality. Let us first assume, for the sake of the argument, that the observed wage dispersion within the industrial labor force is representative for the entire wage-earning population and that the entire income earning population receives a wage in addition to possible other sources income. As shown in Table 6, the shares would then have gone up from $2-11 \%$ around the year 1960 to $15-21 \%$ around the year 2000 . The unaccounted part of total income inequality should be attributed to the interpersonal distribution of capital income. Capital income is always more unequally distributed, as only a minority of income earners tends to derive a substantial amount of income from asset ownership. Moreover, within this minority, a much smaller elite category of "super wealthy" represents the "top incomes" in the overall income distribution (Piketty and Saez 2006).

Table 6 Comparing Theil coefficients of inter-industry wage inequality and total income inequality in Argentina, Brazil, and Chile, 1960-2002

\begin{tabular}{llllr}
\hline & Years of observation & $\begin{array}{c}\text { Wage inequality (A) } \\
\text { Theil coeffecient }\end{array}$ & $\begin{array}{l}\text { Income inequality (B) } \\
\text { Theil coeffecient }\end{array}$ & A/B \\
\hline Argentina & $1963 / 1961$ & 0.003 & 0.127 & 0.02 \\
\multirow{2}{*}{ Brazil } & $2001 / 2001$ & 0.034 & 0.214 & 0.16 \\
& $1962 / 1960$ & 0.022 & 0.24 & 0.09 \\
Chile & $2002 / 2001$ & 0.062 & 0.292 & 0.21 \\
& $1968 / 1968$ & 0.02 & 0.175 & 0.11 \\
\hline
\end{tabular}

For total income inequality, data have been retrieved from the UNU-WIDER, World Income Distribution Database, version 2.0c. Wage inequality data are presented in this study (see "The Post-War Rise of Latin American Wage Inequality, 1950-20004" section)

The Theil coefficient of income inequality in Argentina 2001 refers exclusively to the urban population 
In reality however, the wage inequality shares presented in Table 6 are lower bound estimates. The interpersonal wage dispersion between all wage earners, engaged in all sectors of the economy, is certainly higher than the inter-industry inequality figures we have been focusing on in this study. For these will include the wages earned in low-productive (informal) service activities, the generally higher wages in the financial or real estate sectors, as well as the generally lower rural wages. It is therefore reasonable to assume that the total contribution of labor income inequality will at least be in the order of $20-30 \%$ of total income inequality in Argentina and Chile and perhaps even higher in Brazil, although there remains a possibility that the inter-industry wage gaps in Brazil provide a better coverage of total labor income inequality than in Argentina or Chile.

Indeed, the rising contribution of wage inequality to income inequality seems beyond doubt, but it is not certain that the rise of wage inequality has been responsible for the upward trend in income inequality as has been witnessed in the majority of LACs since the 1970s (Psacharopoulos et al. 1997; Morley 2001). When increasing skill premiums (or sector premiums) contribute to the growth of a middle class, the net effect of increasing wage differentials can go in either direction: it increases inequality among wage earners, but may reduce the income gap between capital owners and (part of) the wage earners. Unfortunately, the lack of reliable capital income distribution data remains a fundamental constraint to reaching conclusive evidence on the net inequality effect of changes in the factor income distribution.

\section{Conclusion}

A long-run comparative analysis of levels and trends in industrial wage inequality has revealed that wage inequality in most LACs was moderate during the first half of the twentieth century. Inter-industry wage gaps (between-group inequality), intraindustry wage gaps (within-group inequality) and gender wage gaps were comparable to other New World countries and considerably lower than in most East Asian countries. In the course of the twentieth century, and especially during its last quarter, Latin American wage inequality rose spectacularly. The rise was remarkably steep in comparison to the pre-war period as well as the trends observed in the USA, Canada, and Australia. Although we found substantial intraregional differences in timing and levels, the rise itself was a shared feature of all the 15 LACs examined in this study.

The rise of Latin American wage inequality cannot be understood without taking the great transformation in the composition of Latin American labor markets into account. Particularly during the second half of the twentieth century, a structural imbalance in the distribution of human capital across the labor force made Latin American economies highly susceptible to skill-biased changes in technology and international competition. The cases of Argentina and Chile have shown that wage gaps exploded after having been compressed for decades. The dramatic widening of sectoral productivity differentials in Brazil shows that some sectors could indeed afford to pay the higher wages to attract skilled workers, or alternatively, could afford to share rents on the basis of monopolistic advantages. This implies that it did 
not necessarily make a difference for levels of wage inequality whether wages were controlled by the state or determined by the market. But more than anything else, all three cases make clear that political-institutional conditions and reforms need to be integrated in theories explaining comparative wage inequality levels and trends in Latin America.

Acknowledgment The author gratefully acknowledges financial support from the Dutch Science Foundation (NWO). The author wishes to thank Leandro Prados de la Escosura, Jaime Reis, Luis Bértola, Leticia Arroyo Abad, Jan Luiten van Zanden, Jan Pieter Smits, Bart van Ark, Harry Garretsen, Michiel Baud, Pitou van Dijk, Herman van der Werfhorst, Debin Ma, Collin Lewis, Albrecht Ritschl, Morton Jerven, and the participants of the session "Origins of economic growth in the nineteenth and twentieth centuries" at the European Social Science History Conference, Lisbon (26 Feb-1 March 2008), the participants of the Third joint Summerschool of GlobalEuronet and the Marie-Curie Research Training Network "Economic and Social Inequalities in Historical Perspective", Paris School of Economics (7-11 July 2008), the participants of the Social Science seminar, University of Amsterdam (23 Sept 2008), and the participants of the Economic History seminar at the London School of Economics and Political Science (14 Jan 2009) and two anonymous reviewers for their valuable comments on previous drafts. The usual disclaimer applies.

Open Access This article is distributed under the terms of the Creative Commons Attribution Noncommercial License which permits any noncommercial use, distribution, and reproduction in any medium, provided the original author(s) and source are credited.

\section{References}

Acemoglu D. Directed technical change. Rev Econ Stud. 2002;69:781-810.

Allen RC. The great divergence in European wages and prices from the Middle Ages to the First World War. Explor Econ Hist. 2001;38:411-47.

Altimir O. Estimaciones de la distribución del ingreso en la Argentina, 1953-1980. Desarrollo Económico. 1986;25:521-66.

Altimir O, Beccaria L, El mercado de trabajo bajo el nuevo regimen económico en Argentina. Serie Reformas Económicas No. 28. ECLAC, 1999. Santiago.

Arbache JS, Carneiro FG. Unions and interindustry wage differentials. World Development. 1999;27:1875-83.

Arellano J-P. Social policies in Chile: a historical review. J Lat Am Stud. 1985;17:398-403.

Arroyo Abad AL, Santos-Paulino AU. Trading inequality? Comparing the two globalization waves in Latin America. 2009. mimeo.

Astorga P, Berges AR, Fitzgerald V. The standard of living in Latin America during the twentieth century. Econ Hist Rev. 2005;68:765-96.

Atkinson AB, Piketty T. Top incomes over the twentieth century. A contrast between continental European and English-speaking countries. Oxford: Oxford University Press; 2007.

Autor DH, Katz L, Krueger A. Computing inequality: have computers changed the labor market? Q J Econ. 1998;113:1169-214.

Autor DH, Levy F, Murnane RJ. The skill content of recent technological change: an empirical exploration. Q J Econ. 2003;188:1279-333.

Bacha EL, Taylor L. Brazilian income distribution in the 1960s: facts, model results and the controversy. J Dev Stud. 1978;14:271-97.

Baer W. The Brazilian economy. Growth and development. 5th. Westport: Praeger; 2001.

Barrett PS. Labor policy, labor-business relations and the transition to democracy in Chile. J Lat Am Stud. 2001;33:561-97.

Beccaria L. Distribución del ingreso en la Argentina: explorando lo sucedido desde mediados de los setenta. Desarrollo Económico. 1991;31:319-38.

Berman E, Machin S. Skill-biased technology transfer around the world. Oxford Review of Economic Policy. 2000;16:12-22.

Berman E, Bound J, Griliches Z. Changes in the demand for skilled labor within US manufacturing: evidence from the annual survey of manufacturers. Q J Econ. 1994;109:367-97.

Berman E, Bound J, Machin S. Implications of skill-biased technological change: international evidence. Q J Econ. 1998;113:1245-79. 
Bértola L. A 50 años de la curva de Kuznets: crecimiento económico y distribución del ingreso en Uruguay y otras economías de Nuevo asentamiento desde 1870. Investigaciones de Historia Económica. 2005;3:135-76.

Bértola L, Williamson JG. Globalization in Latin America before 1940. In: Bulmer-Thomas V, Coatsworth JH, Cortés Conde R, editors. The Cambridge economic history of Latin America. Volume II: the long twentieth century. Cambridge: Cambridge University Press; 2006. p. 11-57.

Bértola L, Castelnovo CR, Javier Willebald H. Income distribution in the Latin American Southern Cone during the first globalization boom, ca: 2008; 1870-1920. Working Papers in Economic History, WP $08-05$.

Birdsall N, Ross D, Sabot R. Education, growth and inequality. In: Birdsall N, Jasperson F, editors. Pathways to growth: comparing East Asia and Latin America (Inter-American Development Bank). Washington DC: Johns Hopkins University Press; 1997. p. 93-130.

Bonelli R, Ramos L. Income distribution in Brazil: longer term trends and changes in inequality since the mid-1970s. Texto Para Discussão No. 288. 1992.

Brown DS. Democracy, authoritarianism and education finance in Brazil. J Lat Am Stud. 2002;34:115-41.

Camps E, Camou MM, Maubrigades S, Mora-Sitja N. Globalization and wage inequality in South and East Asia, and Latin America: a gender approach. Working Paper presented at the International Economic History Conference Helsinki. 2006.

Cárdenas M, Bernal R. Changes in the distribution of income and the new economic model in Colombia. Serie Reformas Económicas. ECLAC. 1998.

Cardoso E, Helwege A. Latin America's economy. Diversity, trends, and conflicts. Cambridge: MIT; 1992.

Carneiro FG. Productivity effects in Brazilian wage determination. World Development. 1998;26:139-53.

Chanduví JS, Díaz JJ. Desigualdad del ingreso y del gasto en el Péru antes y después de las reformas estructurales. Serie Reformas Económicas. ECLAC. 1998.

Clark G. A farewell to Alms. A brief economic history of the world. Princeton: Princeton University Press; 2007.

Coatsworth JH. Inequality, institutions and economic growth in Latin America. J Lat Am Stud. 2008;40:545-69.

Colistete RP. Productivity, wages, and labor politics in Brazil, 1945-1962. J Econ Hist. 2007;67:93-127.

Collier S, Sater WF. A history of Chile 1808-2002. 2nd. Cambridge: Cambridge University Press; 2004.

De Ferranti D, Perry GE, Ferreira FHG, Walton M. Inequality in Latin America. Breaking with history? World Bank Latin American and Caribbean studies. Washington, DC: World Bank; 2004.

Prados de la Escosura L. Growth, inequality and poverty in Latin America: historical evidence, controlled conjectures. Working paper in Economic History. 2005. 05-41 (04).

De Soto H. The mystery of capital. Why capitalism triumphs in the West and fails everywhere else. New York: Basic Books; 2000.

Engerman SL, Sokoloff KL. Factor endowments, institutions, and differential Paths of Growth among New World Economies: a view from economic historians of the United States. In: Haber S, editor. How Latin America Fell Behind. Essays on the Economic Histories of Brazil and Mexico, 18001914. Stanford: Stanford University Press; 1997. p. 260-304.

Engerman SL, Sokoloff KL. Colonialism, inequality and long-run paths of development. NBER working paper 11057. 2005.

Feenstra RC, Hanson GH. Global production sharing and rising inequality: a survey of trade and wages. In: Choi K, Harrigan J, editors. Handbook of international trade. Malden: Basil Blackwell; 2003. p. $146-85$.

Ferreira FHG, Litchfield JA. Calm after the storms: income distribution in Chile, 1987-1994. World Bank Policy Research Paper. Washington, DC: World Bank; 1998.

Fontagne LG, Mirza D. International trade and rent sharing among developed and developing countries. Econ Model. 2007;24:523-58.

Frank V. The elusive goal in democratic Chile: reforming the Pinochet Labor Legislation. Latin American Politics and Society. 2002;44:35-68.

Frankema EHP. Comparing the distribution of education across the developing world, 1960-2005: what does the grade enrollment distribution tell about Latin America? Soc Indic Res. 2008;88:437-55.

Frankema EHP. The expansion of mass education in twentieth century Latin America: a global comparative perspective. Revista de Historia Económica. 2009a;27:359-95.

Frankema EHP. Has Latin America always been unequal?: A comparative study of asset and income inequality in the long twentieth century. Boston: Brill; $2009 \mathrm{~b}$.

Frankema EHP. Reconstructing labor income shares in Argentina, Brazil and Mexico, 1870-2000. Revista de Historia Económica. 2010;28:343-74. 
Frankema EHP, Smits JP. Exploring the historical roots of Eastern Asia's post-war catch-up growth: a trade perspective, 1906-1999. Journal of the Asia Pacific Economy. 2005;10:178-94.

Freeman RB. Are your wages set in Beijing? J Econ Perspect. 1995;9:15-32.

Galbraith JK, Berner M. Inequality and industrial change. A global view. Cambridge: Cambridge University Press; 2001.

Galbraith JK, Kum H. Inequality and economic growth: data comparisons and econometric tests. University of Texas Inequality Project (UTIP) working paper no. 21. 2002.

Galiani S, Gerchunoff P. The labor market. In: della Paolera G, Taylor AM, editors. A new economic history of Argentina. Cambridge: Cambridge University Press; 2003. p. 122-69.

Galiani S, Porto GG. Trends in Tariff reforms and trends in the structure of wages. SSRN working paper. 2008.

Galiani S, Sanguinetti P. The impact of trade liberalizationon wage inequality: evidence from Argentina. J Dev Econ. 2003;72:497-513.

Galor O, Zeira J. Income distribution and macroeconomics. Rev Econ Stud. 1993;60:35-52.

Goldin C, Katz L. The origins of technology-skill complementarity. Quarterly J Econ. 1998;113:693-732.

Helpman E. The mystery of economic growth. Cambridge: The Belknap Press of Harvard University Press; 2004.

Kay C. Asia's and Latin America's development in comparative perspective: landlords, peasants and industrialization. ISS working paper series no. 336. 2001.

Langoni CG. Distribuição de Renda e Desenvolvimiento Econômico do Brasil. Rio de Janeiro: Editora Expressão e Cultura; 1973.

Langoni CG. Distribuiçã da Renda: Uma Versão para a Minoria. Pesqui Planej Econ. 1974;4:167-80.

Levine RM. The history of Brazil. New York: Palgrave Macmillan; 1999.

Levy F, Murnane RJ. US earnings levels and earnings inequality: a review of recent trends and proposed explanations. J Econ Lit. 1992;30:1333-81.

Lewis PH. The crisis of Argentine capitalism. Chapel Hill: University of North Carolina Press; 1990.

Lindert PH. Growing public. Social spending and economic growth since the eighteenth century. Cambridge: Cambridge University Press; 2004.

Lindert PH. The unequal lag in Latin American schooling since 1900: follow the money. Revista de Historia Económica. 2010;28:375-405.

Londoño JL, Székely M. Persistent poverty and excess inequality: Latin America, 1970-1995. J Appl Econ. 2000;3:93-134.

Macedo RB. A critical review of the relation between the post-1964 wage policy and the worsening of Brazil's size income distribution in the sixties. Explorations in Economic Research. 1977;4:117-40.

Mariscal E, Sokoloff KL. Schooling, suffrage, and inequality in the Americas, 1800-1945. In: Haber S, editor. Political institutions and economic growth in Latin America. Essays in policy, history, and political economy. Stanford: Hoover Institution Press, Stanford University; 2000. p. 159-217.

Mookerjee D, Ray D. Persistent inequality. Rev Econ Stud. 2000;70:369-93.

Morley S. The income distribution problem in Latin America and the Caribbean. Santiago de Chile: UN, ECLAC; 2001.

Ocampo JA, Martin J. Globalization and development. A Latin American and Caribbean perspective. Palo Alto: ECLAC, World Bank, Stanford University Press; 2003.

Park YB, Ross D, Sabot R. Educational expansion and the inequality of pay in Brazil and Korea. In: Birdsall N, Sabot R, editors. Opportunity forgone: education in Brazil (Inter-American Development Bank). Washington DC: Johns Hopkins University Press; 1996. p. 267-88.

Perry G, Olarreaga M. Trade liberalization, inequality and poverty reduction in Latin America. Paper presented at ABCDE, St. Petersburg. 2006.

Phelps Brown H, Hopkins SV. Seven centuries of the price of consumables, compared with builders' wage rates. Economica. 1957;23:296-314.

Piketty T, Saez E. The evolution of top incomes: a historical and international perspective. NBER working paper 11955. 2006.

Psacharopoulos G, Morley S, Fiszbein A, Lee H, Wood B. Poverty and income distribution in Latin America. The story of the 1980s. World Bank technical paper no. 351. Washington DC: World Bank; 1997.

Richardson JD. Income inequality and trade: how to think, what to conclude. J Econ Perspect. 1995;9:3355.

Rock D. Argentina 1516-1987. From Spanish colonization to Alfonsín. Berkeley: University of California Press; 1987. 
Romero LA. A history of Argentina in the twentieth century. Philadelphia: Pennsylvania State University; 2002.

Székely M, Montes A. Poverty and inequality. In: Bulmer-Thomas V, Coatsworth JH, Cortés Conde R, editors. The Cambridge economic history of Latin America. Volume II: the long twentieth century. Cambridge: Cambridge University Press; 2006. p. 585-645.

Theil H. Economics and information theory. Amsterdam: North-Holland; 1967.

Theil H. Statistical decomposition analysis: with applications in the social and administrative sciences. Amsterdam: North-Holland; 1972.

Thorp R. Progress, poverty and exclusion. An economic history of Latin America in the twentieth century. Inter-American Development Bank. New York: The Johns Hopkins University Press; 1998.

Waisgras S. Wage inequality and the labor market in Argentina: labor institutions, supply and demand in the period 1980-99. International Institute for Labor Studies discussion paper no. 146. 2003.

Wegenast T. Of Latifundia and Coronéis: Agrarian structure and educational inequalities in Brazil. Working paper presented at the Mini-Conference "A Comparative Approach to Inequality and Development: Latin America and Europe”. 8-9 May, 2009. Madrid. 2009.

Wells J, Drobny A. A Distribuiçã de Renda e o Salario Mínimo no Brasil: Uma Revisão Crítica da Literatura Exsitente. Pesquisa e Planejameto Econômico 12. 1982.

Williamson JG. Real wages, inequality and globalization in Latin America before 1940. Revista de Historia Económica. 1999;17:101-42.

Williamson JG. Land, labor and globalization in the Third World 1870-1940. J Econ Hist. 2002;62:55-85.

Wood A. North-south trade. Employment and inequality. Changing fortunes in a skill-driven world. Oxford: Clarendon; 1994.

Wright TC. Landowners and reform in Chile. The Sociedad Nacional de Agricultura. Urbana: Univeristy of Illinois Press; 1982. p. 1919-40.

Ewout Frankema obtained his $\mathrm{PhD}$ in Economics (2008) from the University of Groningen and is presently affiliated to Utrecht University as Assistant Professor of Socio-Economic History. His main research interests evolve around the themes of long term economic development, global inequality and colonial history with an emphasis on sub-Saharan Africa and Latin America. Dr. Frankema is co-director of the N.W. Posthumus Institute research programme Drivers and Carriers of Globalisation, co-executive editor of the Low Countries Journal of Social and Economic History and member of the editorial board of Economic History of Developing Regions. Current research projects include the Colonial origins of inequality: a comparative analysis of fiscal regimes in Asia, Africa and the New World (with support from the Dutch Science Foundation) and Colonial exploitation and economic development: The Belgian Congo and the Dutch East Indies compared (with support from the combined Dutch and Flemish Science Foundation). Key publications include Has Latin America always been unequal? A comparative analysis of asset and income inequality in the long twentieth century, Brill (Leiden 2009) and 'Colonial taxation and government spending in British Africa, 1880-1940: Maximizing revenue or minimizing effort?', Explorations in Economic History 48, 1 (2011). 